\title{
Pendurado nas botas do Barão: reflexões sobre (meus) processos de subjetivação
}

Hung on the Baron's boots: reflections about (my)

subjectivation processes

\section{Carlos Eduardo Silva}

Carlos Eduardo Silva Ator, bonequeiro, iluminador e diretor teatral. Doutorando em Literatura pelo Programa de Pós-Graduação em Literatura da Universidade Federal de Santa Catarina (PPGLIT/UFSC)

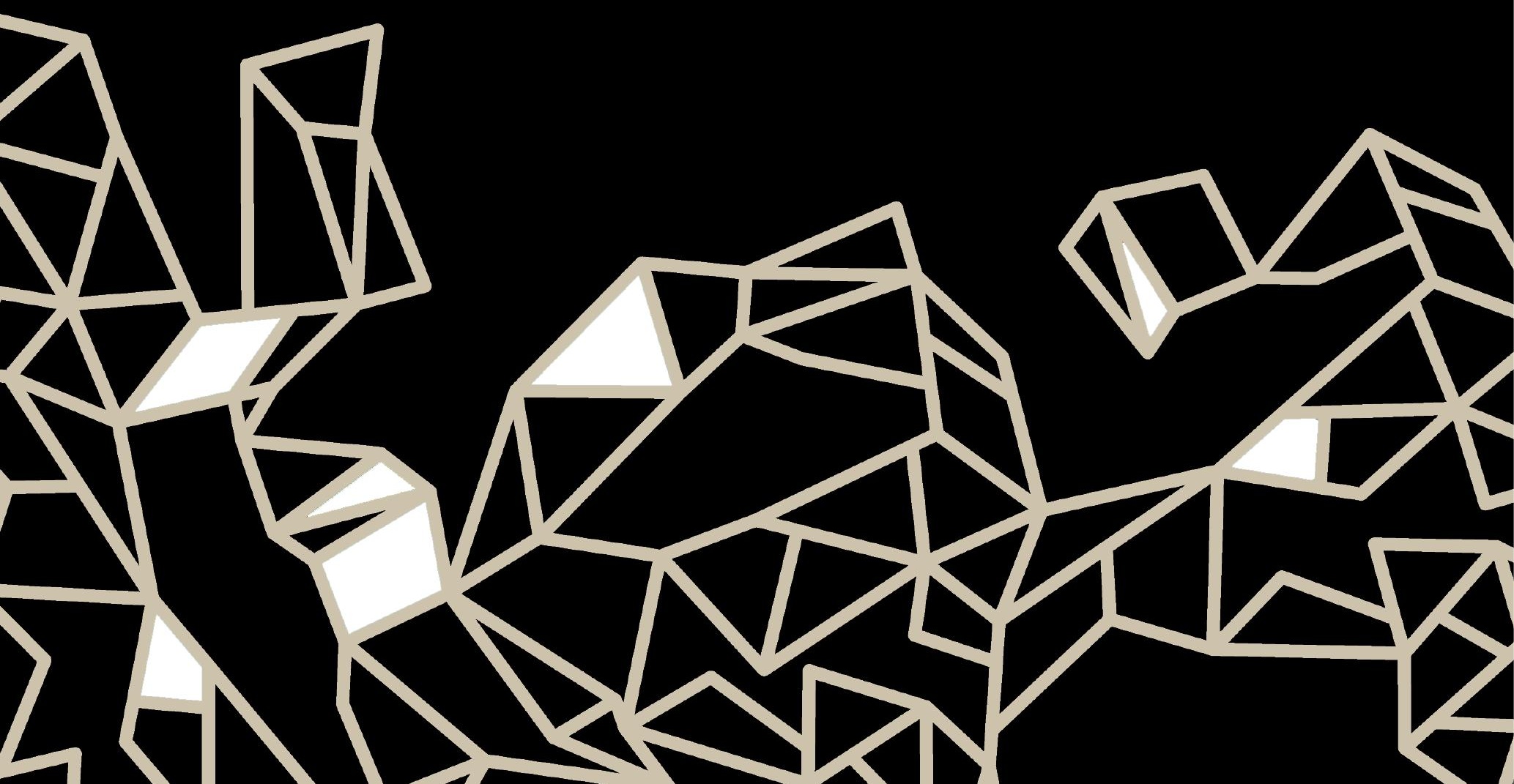




\section{Resumo}

Este artigo reflete sobre a polissemia dos conceitos de identidade, sujeito e subjetivação, descobrindo-os a partir, especialmente, de Bauman, Moreno, Lacan, Maheirie, Deleuze, Foucault e Rolnik. Além disso, assumo minha pesquisa em ópera como a arte mediadora do meu processo de subjetivação atualmente, e critico a falta de porosidade em muitos processos operísticos enquanto instâncias públicas que poderiam ser atravessadas por diversas forças político-sociais, mas que resultam na desatualização do gênero e desvinculação da vida cotidiana da sociedade moderna.

Palavras-chave: Identidade, Sujeito, Subjetivação, Ópera, Desatualização.

\section{Abstract}

This paper reflects on the multiple meanings of the concepts of identity, subject and subjectivation, discovering them especially from Bauman, Moreno, Lacan, Maheirie, Deleuze, Foucault and Rolnik. Furthermore, I take my research in opera as an art mediator to my subjectivation process nowadays, and criticize the lack of porosity in many operatic processes as public instances that could be crossed by various political and social forces, but resulting in obsolescence of its gender and untying of everyday life of modern society.

Keywords: Identity, Subject, Subjectivity, Opera, Obsolescence.

\section{Pendurado onde?}

Não me venha com segredos.

E olha que não acredito em verdades.

Verdades são como a sola do sapato que cobre a sola do pé. Você pensa que me dói a brasa na sola do pé, mas não vê a dor da brasa entre a sola do sapato e a sola do pé. Pulo, e logo penso: o logos, o fogo.

(GLENADEL, 2008, p. 40) 
De saída, devo admitir que enfrento uma enorme dificuldade em fazer este artigo em primeira pessoa, senão no todo, em boa parte; mas um projeto que visa refletir criticamente o processo artístico e de pesquisa como mediadores do processo de subjetivação, colocando o próprio autor como objeto da análise, não poderia fugir desse formato. O desconforto está tanto na falta de hábito de manifestação de autotestemunho, um vício da escrita acadêmica, quanto na tentativa de fugir das confissões vulgares que mais aproximariam este trabalho de uma autoanálise ou de um memorial descritivo, desviando a reflexão crítica e consciente da formação do eu, ou do eu em devir. Apesar disso, soa desafiador falar do meu processo de subjetivação na relação com outros sujeitos em devir.

É absolutamente dificultoso, para não empregar a palavra impossível, falar de si com distanciamento e imparcialidade. Como fazê-lo? Para expressar tamanho desafio, me ocorre a alegoria do Barão. Em fins do século XVIII, o livreiro alemão Rudolf Erich Raspe narrou a existência de um nobre e aventureiro contemporâneo seu chamado Karl Friedrich Hieronymus von Munchhausen. Os feitos e peripécias desse fidalgo foram imortalizados por Raspe através da obra "As aventuras do Barão de Munchausen." Nela, o nobre aparece realizando as proezas mais fantásticas, como voar sentado em uma bala de canhão, viajar à lua e, a mais famosa, fugir do pântano puxando a si mesmo pelos cabelos. Pois é como me vejo quando na posição de discutir conceitos relacionados a minha subjetivação. Como sair do charco puxando-se a si próprio? Não sei... pelo menos vou tentar sair pendurado pelas botas do Barão, já que ele conseguiu!

Dessa forma, para evitar incorrer em algum equívoco metodológico e, mormente, tomar por subjetividade, sujeito e identidade aquilo que não o seja, pretendo compreender algumas linhas teóricas que melhor acolhem e definem a constituição daquilo que me faz a singularidade que sou, e não outro. Procuro em que medida tal processo constitutivo dialoga com outras subjetividades e o quanto o projeto poético que intermedia meu processo de subjetivação mostra-se como instância pública, isto é, em contato com o meio social, e poroso ao outro e aos outros no sentido de estar aberto a ser afetado, interferido, pelas forças que o atravessam.

Acredito que diversas perspectivas sobre o tema manifestam um caminho interessante para refletir a questão e, de igual forma, melhor respondem à com- 
plexidade do assunto abordado. Não obstante meu intento inicial de buscar compreender, expondo os conceitos elementares do que julgo ser e envolver o processo de subjetivação - amparado pelos autores anteriormente citados -, não pretendo estabelecer uma linha lógico-racional nem histórico-evolutiva para definir tal processo, tampouco um conceito universal e determinístico. Ao contrário, a pluralidade conceitual só vem enriquecer as possibilidades de entendimento.

Portanto, para conseguir me manter pendurado, buscarei a compreensão do processo de subjetivação a partir da confluência de quatro campos do saber, quais sejam: a filosofia, a psicologia social, a filologia e o teatro. Assim, chego a Foucault e à subjetivação do indivíduo através de aleturgia e parresía; Maheirie sobre a noção de identidade, sujeito e subjetivação; Bauman e processos identitários; Moreno e a teoria dos papéis. Além disso, pretendo alcançar em Bakhtin a imbricação do conceito de polifonia e intertextualidade na constituição da subjetivação; e em Rolnik a formação da subjetividade no trânsito entre o micro e o macro político. Finalmente, chego às minhas experiências atuais na pesquisa, que visa colocar a ópera em análise justamente como obra de arte aberta e porosa às interferências do nosso tempo, tomando-a como contexto e matriz de encontros, geração de afetos, diálogo com a sociedade e atravessamento de múltiplos e distintos enunciados nessa forma de arte cênica. Enfim, encaro a ópera como mediadora do processo de subjetivação em que me encontro e potencial mediadora de outras subjetivações.

\section{Persona, Personalidade, Identidade.}

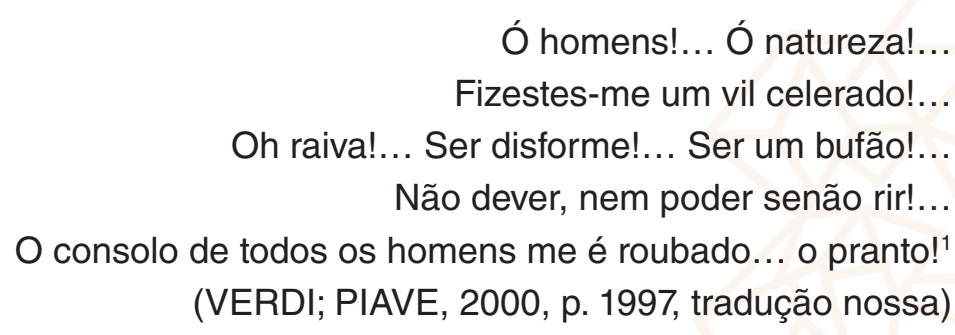

Parece-me existir uma linha tênue que perpassa e até confunde a noção de subjetivação, sujeito e identidade. A impressão que me surge é que

1 Original: "O uomini! O natura!... Vil scellerato mi faceste voi!... O rabbia!... Esser difforme!... Esser buffone... Non dover, no poter altro que ridere!... II retaggio d'ogni uom m'è tolto... il pianto...." 
subjetivação é uma construção continuada, já que as palavras terminadas em "-ção" geralmente são substantivos derivados de verbos, de ações, que dão a ideia de processo. Subjetivação, assim, se referiria ao processo de construção da identidade que faz do indivíduo um sujeito, ou seja, seria a própria atualização sempre em curso da identidade no tempo e no espaço. A identidade seria, dependendo da perspectiva adotada, tanto a faceta externa, social, da personalidade quanto a noção de reconhecimento e pertencimento de um indivíduo a sua comunidade, mas isso, confesso, é uma conceituação própria e imprecisa que pretendo confrontar e verificar até que ponto me distancio das correntes teóricas que apresentarei a seguir. Em verdade, este é um artigo que surge como uma descoberta tanto dos conceitos quanto do conceituado; não tenho nada a priori.

Para falar dessa matéria que nos constitui como individualidade e da importância do teatro na compreensão da psique humana, recorro ao velho Rigoletto, o bobo da corte do ducado de Mântua. Sua sina era divertir o Duque e seus cortesãos entre piadas, provocações e deboches. Não por acaso, adquiriu muitos desafetos. Corcunda e sempre caracterizado, o personagem, poderia ser um tipo fácil, isto é, um estereótipo nada crível nem realista, habitável somente no universo das ficções que retratam simplistamente o universo humano representando um aspecto isolado de nossa personalidade. No entanto, esse bufão talvez tenha sido o primeiro personagem da tradição operística que se aproxima da complexidade humana por uma razão: ele sofre por ser quem é.

O aspecto humano em Rigoletto está na contradição dos sentimentos que o personagem apresenta: seu prazer de atentar contra a moral da elite corrupta, retrógrada e aduladora do poder; por outro lado, sua dor reside na vergonha de fazer o que faz e ser quem é, ao ponto de sua própria e única filha não saber a profissão do pai nem o nome do genitor. Nesse ponto, Rigoletto muito se aproxima de todos aqueles que, como ele, têm sempre algo a esconder de si, algo tão oculto que até os mais amados não ousariam perscrutar.

Coração de gente é terra que ninguém passeia, e o daquele servo do ducado de Mântua é nos dado a conhecer apenas uma ínfima parte; todo o restante encontra-se encoberto pelo véu da vergonha e da conveniência de se ser quem é. Porém, todo o conflito de Rigoletto só faz sentido ante a perspectiva do outro. Os males d'alma do palhaço não são isolados, mas 
estão dados na relação social em que ele está inserido. A deformidade física não é motivo de constrangimento senão diante da reação alheia, e a constante tentativa de provocar a nobreza vem como resposta às humilhações sofridas e como autoafirmação.

Rigoletto é um personagem, um ente teatral roubado pela sensibilidade musical de Verdi e seu libretista, Piave, da obra literária Le Roi S'amuse, de Victor Hugo, na qual o paralelo é Triboulet. Assim como, dramaturgicamente, a representação da individualidade se dá através da tentativa de construção de personagens que expressem as mesmas problemáticas humanas, imageticamente, uma das formas de expressar essa constituição foi a máscara. Porém, a máscara é estática em sua forma, donde provém uma equivocada noção de imobilidade da persona. Além disso, a máscara também necessita da perspectiva do outro, como algo a ser visto, para fazer sentido, é o filtro da própria imagem.

Todos esses conceitos se referem ao indivíduo como singularidade e manifestam uma dialética inevitável entre a dimensão do indivíduo e do coletivo e da construção da personalidade e sua aproximação do conceito de identidade a partir do trânsito entre esse binômio. Basta lembrar-se do teatro grego, no qual temos o coro como exemplo de supressão da individualidade pela força e importância da coletividade expressa na sincronia do discurso comum e homogeneidade de caracterização (figurino, máscaras etc.). Contudo, somente quando uma voz destoa da multidão a individualidade nasce, ganhando destaque e desvinculando-se do grupo, do qual advém aquilo que modernamente conhecemos como personagem.

Por essa razão, o dicionário etimológico italiano, refere-se à personagem como aquela que "faz soar" através da máscara grega, per-sona²; daí deriva "personagem", "pessoal” ("personal” em outras línguas de matriz ou influência latina, por exemplo), "personificar", etc. A noção de personalidade está intimamente ligada àquele que tem voz, opinião e discursos próprios, enfim, singularidade. Portanto, a máscara dissolvia o personagem no coro ou o individualizava, facilitando a identificação, dando-lhe identidade no meio de um palco repleto de tantos outros elementos, num tempo cuja tecnologia não

2 Disponível em: <http://www.etimo.it/?term=persona>. Acesso em: 6 dez. 2016. 
permitia focos luminosos definidos e específicos para destacar alguém. Entretanto, sua utilidade e funcionalidade estão necessariamente condicionadas ao olhar de outrem.

O que venho expondo é que personalidade e identidade podem ser tomadas como dimensões da subjetividade, sem que nisso haja antonímia. A construção dessas duas noções está vinculada às interferências do meio social, ao contato com o outro, e são dadas sempre em perspectiva, o que resulta num conhecimento que é sempre fragmentário, uma parte do que se viu. Essa noção de personagem revelado por suas características externas de comportamento e feição foi dando, ao longo dos séculos, a compreensão de personalidade e identidade que chegou até nós pela perspectiva da psicologia, em especial a freudiana.

Para a Psicologia Social, há muita polêmica e contradição no conceito de identidade. Há quem o compreenda como algo acabado e, por isso, estático e definitivo; ou inacabado, logo, dinâmico e mutável. Noutra perspectiva, encontramos o conceito relacionado ao vínculo de reconhecimento do sujeito para com a sua comunidade ou mesmo associado à identificação do aspecto externo, comportamental, da personalidade de um indivíduo. Isso só corrobora para uma polissemia sobre o termo, conforme se nota:

Se, tradicionalmente, identidade tem o significado de uma unidade de semelhanças se fechando na permanência, outras perspectivas do conceito têm sido desenvolvidas na Psicologia Social e outras disciplinas das ciências humanas e sociais. (MAHEIRIE, 2002, p. 39)

Bauman (2005) fala de identidade, mas por um caminho antropológico que se aproxima também da Psicologia Social. Para o polonês, a identidade não é uma composição de características de personalidade, mas uma relação de vínculo social, de pertencimento da manifestação no sujeito da herança que recebe de certos valores, crenças e paradigmas comunitários. Daí se segue, por exemplo, a identidade cultural. Nesse caso, a identidade produz um sentido de reconhecimento, como podemos notar com relativa clareza na semelhança de modos, costumes e convenções dos membros de uma mesma tribo, comunidade, grupalidade etc. Essa relação não possui solidez sendo, consequentemente, líquida e dinâmica. 
Na mesma direção aponta Sawaia (1996, p. 58), dizendo que "identidade é uma categoria política disciplinadora das relações entre as pessoas, grupo ou sociedade, usada para transformar o outro em estranho, igual, inimigo ou exótico". Portanto, identidade não está no campo do apreço ou admiração por alguém, mas da normatização e categorização social, da divisão dos grupos, castas, guetos, classes e que determina a composição de cada um desses agrupadores.

Para Souza Santos (1995), a identidade pode ser compreendida como um permanente processo de síntese de identificações, "resultados sempre transitórios e fugazes de processos de identificação [...] identidades são, pois, identificações em curso". (p. 135) Tomada deste ponto de vista, a identidade não pode ser dada como algo consolidado, mas em devir, resultante sempre de movimentos complexos e, não raro, contraditórios de teses e antíteses. Segundo Maheirie (2002, p. 41):

A construção da identidade tem a marca da ambiguidade, da síntese inacabada de contrários, daquilo que é individual e coletivo, daquilo que é próprio e alheio, daquilo que é igual e diferente, sendo semelhante a uma linha que aponta ora para um polo, ora para outro. A utilização do conceito de identidade nos permite desvelar os indivíduos, grupos ou coletividades, localizá-los no tempo e no espaço "identificando-os" como estes e não outros, mesmo em metamorfose.

De acordo com Lago (1996), a questão identitária tem relação com o ser que, tomando consciência de si, distingue-se dos demais, isto é, individualiza-se, diferencia-se. Assim, pela abordagem da singularidade, a identidade como uma dimensão da consciência de si sofre a interferência direta dessa conscientização, enquanto, pelo viés social, a relação com os demais indivíduos, age como auto diferenciador. É um movimento de dentro para fora e de fora para dentro.

Segundo Moreno (1994, p. 27), "o papel é a forma de funcionamento que o indivíduo assume no momento específico em que reage a uma situação específica, na qual outras pessoas ou objetos estão envolvidos." Dessa forma, a identidade se desenvolve a partir do papel, da função que se exerce perante a coletividade. "O papel é a unidade da cultura: ego e papel estão em contínua interação." (MORENO, 1972, p. 29) Portanto, em vez de o grupo nascer da associação das individualidades que fazem do coletivo a somatória de suas identidades articuladas através das relações interpessoais, para Moreno (1972) a 
identidade dos indivíduos é que nascem da comunidade, e o fortalecimento das relações interpessoais consolida e estabelece os aspectos identitários.

A função, o papel, que um indivíduo desempenha, forja a sua identidade perante o meio ao qual pertence. De outro modo, quem não tem papel algum ou uma função de importância reduzida tende a uma identidade inexpressiva no âmbito social. Esse conceito de Moreno tende a uma abordagem utilitária das relações interpessoais, que são vinculadas a uma serventia dentro do que as convenções sociais vigentes determinam que seja útil ou importante.

Bakhtin não foi propriamente um psicanalista ou um filósofo, e sua escrita envolve mais a filologia, por isso Bezerra (2010) entende que, para o autor russo, o indivíduo é constituído por uma infinidade de discursos, vozes e signos diversos e de múltiplas instâncias e proveniências. Essa constituição não é biológica ou química, evidentemente, mas diz respeito diretamente à subjetivação do indivíduo, da perspectiva bakhtiniana. Logo, essa multiplicidade de vozes, essa polifonia, produz a singularidade que somos, estabelece nossa identidade numa intersecção tanto maior quanto for a nossa interação com o meio cultural de onde surgimos.

Para Deleuze, no entanto, não há identidade. Em Diferença e repetição (DELEUZE, 2006) o autor defende que, na repetição, nunca temos como resultado algo idêntico. Enquanto os demais autores veem esse movimento como natural e característico do processo da identidade, o filósofo toma o termo ao pé da letra e o compreende como algo estático, por isso o repele. Na filosofia deleuziana, assinatura é o conceito alternativo e apropriado para combater a noção de uma imagem unívoca do indivíduo. A ideia de identidade serve aos meios de singularização e serialização do indivíduo pela sociedade do controle. O pensador francês aproxima-se do compatriota Michel Foucault, para quem os meios de identificação exigem uma forma estática e definitiva de reconhecimento do indivíduo.

Já a assinatura foi prevista anteriormente por Agamben (2009) a partir de leituras de Foucault e Benjamin e refere-se à ideia carregada de uma intencionalidade de um assinante que significa, marca, assina, inscreve-se num tempo-espaço. Na filosofia, a noção de assinatura é indissociável do ato da enunciação, estando presente no corpo e no gesto do indivíduo. Porém, é um ato único, irreproduzível, singular, jamais idêntico ao anterior, que não se repete por encontrar diferença na repetição. 


\section{Dimensões do eu: a consciência, o sujeito e a subjetivação.}

Eu

quando olho nos olhos sei quando uma pessoa está por dentro ou está por fora quem está por fora não segura um olhar que demora de dentro do meu centro este poema me olha (Leminski, 2013, p. 35)

Para Lacan (1998), o indivíduo é, antes de tudo, um ser vivo, um ente biológico, um bios ${ }^{3}$. A medida que esse ser vivo vai entrando em contato com seus pares, começa a interagir pela forma comum, a linguagem, e assim se torna um bios politikos ${ }^{4}$, um ser capaz de interação social, de interpretar e produzir os códigos comunicacionais dogrupo. Esse ser é um sujeito cortado, atravessado, pelo discurso.

Segundo Maheirie, sujeito é aquele que surge da consciência enquanto negação do próprio ser, isto é, a consciência coloca o indivíduo em relação consigo como se fosse outro, um objeto externo; "ela se faz sempre consciência daquilo que ela não é, com relação efetiva a esse objeto". (MAHEIRIE, 2002, p. 33) Essa noção é importante a medida que associa a ideia de sujeito à consciência de si, e subjetivação como o processo contínuo que media a relação do indivíduo com o que o torna sujeito. À vista disso, o processo de subjetivação corresponde ao próprio curso dessa conscientização de si, porquanto conforme vai conhecendo-se, percebendo-se, o indivíduo fortalece as convicções daquilo que é.

Todavia, a conscientização, como o movimento de inflexão de quem deixa de ser quem é para observar-se de fora e assim saber de si, é uma

3 Palavra grega que significa "vida". Disponível em: <http://www.dicionarioetimologico.com. br/bio/>. Acesso em: 6 dez. 2016.

4 Palavra grega que significa "político", "cívico". Disponível em: <http://www.dicionarioetimologico.com.br/politico/>. Acesso em: 6 dez. 2016. 
contradição quando, dialeticamente, nota-se que para saber de si o indivíduo precisa deixar de sê-lo. Logo, a consciência joga com esse deslocamento virtual sobre si, um transporte fictício, para ter clareza, pelo pseudoautodistanciamento, "do quem" e "o que" sou eu. Continua a autora: "consciência, para-si e subjetividade são conceitos que se referem à mesma coisa: a dimensão do sujeito, que é capaz de negar a objetividade (em-si) como uma dimensão absoluta." (MAHEIRIE, 2002, p. 33) Cabe lembrar que, segundo a autora, a subjetividade e o sujeito, numa perspectiva ontológica, não são sinônimos, mas a primeira é uma dimensão do segundo.

Esse processo, que podemos definir como um gesto psíquico, íntimo, pode dar a impressão de autossuficiência do indivíduo naquilo que concerne a sua conscientização. Mas para Spinoza (2013), só se conhecem as potencialidades de um corpo através de outros corpos. As potências de um corpo só podem ser conhecidas pelo contato com outros que revelam as possibilidades daquele que estiver sendo afetado. Assim, se um encontro produz o afeto de alegria ou tristeza, aumento ou diminuição de potência de existir, isso é tão importante quanto a consciência de que essa experiência é mediadora do processo de subjetivação.

Do ponto de vista social, na filosofia spinozana, encontramos o amparo, ainda que anacrônico, à importância das relações interpessoais como agentes de subjetivação, de atravessamento social. Através das relações, os indivíduos permeiam-se daquilo que transita na sociedade. A filosofia dos afetos depende, na sua concretude, da noção de encontro. A variação das potências não ocorre virtualmente, mas pela ação real de (o encontro com) outro corpo. Ação cuja intensidade maior ou menor só pode ser definida na materialidade do encontro de que resulta. Algo paralelo ao que encontramos na dialética exposta pela fala de Maheirie, conforme segue:

[...] o sujeito é objetividade (pois é corpo) e subjetividade (pois é consciência) não podendo ser reduzido a nenhuma dessas duas dimensões. $\mathrm{O}$ eu, ou a identidade, ou a especificidade do sujeito, aparece como produto das relações do corpo e da consciência com o mundo, consequência da relação dialética entre objetividade e subjetividade no contexto social. (MAHEIRIE, 2002, p. 35) 
O sujeito não está apenas numa, mas é ele mesmo, uma zona de imbricações, convergências e divergências de forças de todo um tecido social, público. Não é possível pensá-lo isoladamente desse contexto, imune aos encontros e interferências e destacado do contato com outros sujeitos tão transitórios nos próprios processos de subjetivação. A partir daí, se explica um olhar transdisciplinar sobre as inúmeras camadas conceituais que visam observar e compreender tal processo. Em Rolnik (2011), a observação se dá no fluxo de forças que se movimentam entre plano macropolítico (fatos e modos de vida em sua exterioridade formal, sociológica) e o micropolítico (forças que agitam a realidade, dissolvendo suas formas e engendrando outras, num processo que envolve o desejo e a subjetividade).

Com isso, encaro meu próprio processo de subjetivação enquanto artista menos pelo viés de cartografia psicanalítica, ou de autoanálise, e mais pelo viés da ética spinozana como conscientizadora de uma conduta diante da dialética dos planos estabelecidos por Rolnik. Minha consciência é um lago ${ }^{5}$, vigilante e observador que aponta quando me traio e sempre estimula a dúvida, a ética é seu veneno agindo. Nessa adequação de conduta que a figura do outro é inserida como alguém sobre quem o meu corpo age e que age sobre mim. No sentido em que Spinoza toma esse termo, a ética diz respeito a um comportamento associado a uma postura que se pretende consciente. Para Rolnik surge contemporaneamente o fenômeno de uma volatilidade na ética das subjetividades, através da qual o sistema hegemônico do capital coopta e compra pelo preço que os valores de mercado vigentes determinam e estipulam, as forças subjetivas e de criação.

A noção de processo de subjetivação, em Foucault, tem a dinâmica que faz referência à teoria da impermanência, de Heráclito, segundo o qual ninguém entra duas vezes no mesmo rio porque não será a mesma pessoa, nem as mesmas águas. Porém, a hermenêutica do sujeito não se limita ao tempo em curso expresso pelo primeiro verbete da designação; envolve, constitui um sistema que se manifesta em colaboração e operação com outras camadas semânticas. Poderíamos, por exemplo, observar o projeto concernente à subjetivação em Foucault a partir de Rolnik, associando-o com os planos macro e micropolíticos.

5 Personagem da peça Otelo, o Mouro de Veneza, de William Shakespeare. 
Foucault (2010a, 2010b) pensou o processo de formação de sujeito associado a práticas do saber, em que o sujeito se constitui em relação à ordem discursiva do saber, isto é, todo um conjunto de saberes que põe o sujeito em relação consigo mesmo. Foi a partir de Foucault que, pela primeira vez na história, a sexualidade passou a ser um fator de subjetivação, de relação comigo mesmo, na qual a formação do sujeito foi tomada em relação a sua sexualidade, com suas práticas sexuais. No deslocamento que Foucault faz, do final dos anos 1970 para os 1980, aborda o processo de subjetivação por outro patamar, num outro binômio; agora esse processo vai dizer respeito à relação entre sujeito e verdade mediada por um certo dizer verdadeiro através de duas maneiras iniciativas: a parresía e a confissão.

A constituição do sujeito produzida no evento que expressa a dialética falsa e verdadeira, oculta e revelada, pode transitar tanto entre a dimensão íntima da consciência, da micropolítica, da mobilização das angústias, medos e desejos quanto no plano macropolítico, dialogando com aspectos da vida coletiva, comunitária. Principalmente, em Foucault, o atravessamento entre esses dois planos é explorado como forma de se entender os mecanismos do governo do homem sobre os homens, como a zona do particular que afeta o social.

Interessa-nos, aqui, no foro íntimo, a parresía na subjetivação, que se trata de um modo de constituição de sujeito, de subjetivação, que se coloca em condições muito particulares de risco e que podem lhe causar consequências pela coragem de manifestar um dizer verdadeiro. Portanto, subjetivação é aquilo no que o indivíduo se transforma na relação consigo mesmo mediado por certa maneira de dizer a verdade, a verdade que diz respeito entre ele e aquele a quem se dirige no ato na enunciação. A questão é menos epistemológica, sobre a questão “o que é a verdade?", e mais ontológica, com relação à disposição do indivíduo colocar-se (seu corpo, sua materialidade) em risco para enunciar um discurso "verdadeiro" por oposição ao falso, ao indizível, ao escondido, seja com palavras ou com outras formas de linguagem.

Alguns exemplos podem ser tomados, como o rapaz que se coloca a frente dos tanques de guerra em Pequim na década de 1980; ou a ativista negra que enfrenta a passeata neonazista na Suécia no ano corrente; ou os alunos paulistas, fluminenses, goianos, paranaenses e de inúmeros outros 
locais, que defendem as escolas públicas dos seus estados usando o próprio corpo para ocupá-las; ou como a presidenta eleita, Dilma Rousseff, que vai ao Senado Federal da República denunciar a farsa de um julgamento político para legitimar a queda da democracia. A parresía são esses gestos, contextualizados, que só podem ser afirmados no ato da enunciação e nunca são dados a priori.

A aleturgia compõe o conjunto metodológico que media os processos de subjetivação pelo dizer verdadeiro, enfrentando suas consequências, seja na parresía ou na confissão. A principal diferença entre os dois conceitos foucaultianos é que, no segundo, o sujeito necessariamente modifica sua relação consigo pelo dizer verdadeiro e assume algo até então oculto, o que nem sempre ocorre na parresía. Por isso, confesso que mesmo sem saber desses conceitos previamente, meus medos nesta vida não têm relação com a perda de bens materiais, integridade física, mental, entes queridos, cerceamento de direitos. Minha grande angústia de artista e indivíduo está associada a não ser parresiasta quando a ocasião de sê-lo apresentar-se, de hesitar quando me for cobrado coragem (pelas mais imprevisíveis razões possíveis) para um dizer verdadeiro no teatro, na academia, na política, na vida.

\title{
Não vou olhar para o meu umbigo
}

\author{
Umbigo meu nome é espelho \\ Não dou ouvidos nem peço conselhos \\ Umbigo meu nome é certeza \\ Só é real o que convém a realeza \\ Umbigo meu nome é verdade \\ Sou o dono do mundo e o rei da cidade \\ Umbigo meu nome é umbigo... \\ Umbigo meu nome é umbigo \\ Eu sou mais eu, dê cá um close no narciso \\ (PIMENTEL; TAVARES, 2002)
}

Falar do próprio processo artístico continua me soando como propaganda eleitoral, quando o candidato esconde os problemas e apresenta os sucessos, inclusive maquiando os próprios feitos com uma ficção criada para 
imortalizá-lo pela melhor história. Não leia isso como uma crítica aos que fazem e, muitas vezes, bem-feitas, suas narrativas de processo; em realidade, estou falando de mim. Porém, minha trajetória de pesquisador, nesse momento, fala mais alto e produz maiores estímulos ao compartilhamento que propriamente minhas ações como diretor de grupo de teatro. Desenvolvo hoje uma pesquisa que aborda a ópera como evento cênico - me afasto de qualquer análise musicológica - e procura atualizá-la como arte popular cuja linguagem de encenação pode se renova mantendo o diálogo com a tradição. Tomo como objeto de análise a ópera Otello, de Verdi e Boito, e investigo os documentos de processo do compositor e seu libretista comparado às montagens mais recentes dessa ópera, a partir dos anos 2000, ao redor do mundo.

Isto posto, meu maior desafio tem sido propor a ópera como obra de arte aberta, cujo acabamento só ocorre na efemeridade de sua apresentação, também porosa às leituras atuais, aos ousados projetos de encenação e às demandas sociais contemporâneas. Para tanto, criei um curso que funciona como projeto de extensão na universidade que sou vinculado chamado "Quem tem medo de ópera?", cujo objetivo é desenvolver uma pedagogia baseada numa hermenêutica possível das obras analisadas e realizar comparações de diversas montagens distintas da mesma ópera, para demonstrar a riqueza e variedade que podem ser encontradas.

Outro problema, que talvez seja o mais grave, é a falta de penetração, de infiltração, da ópera na grande maioria da população brasileira. Essa arte não reflete no seu formato aristocrático e estilizado, o cotidiano, os problemas e a realidade do homem moderno, muito menos do homem moderno popular. Dessa forma, não resta a essa arte desatualizada e estagnada no tempo outro espaço senão tornar-se mero entretenimento para as elites pseudointelectuais quando, noutros tempos, a ópera provocou e escandalizou uma sociedade burguesa, machista e conservadora colocando em cena uma mulher financeira e sexualmente livre como protagonista (La Traviata); um empregado que odiava seu patrão (Rigoletto); uma mulher jovem branca apaixonada por um homem negro mais velho (Otello); a fracassada e explorada classe trabaIhadora (La Bohème); o povo judeu como protagonista (Nabucco), quando o antissemitismo tornava-se um problema agudo. 
Como tirar o aspecto empoeirado das óperas? Fazê-las respirar os ares do tempo em que forem apresentadas em vez de representarem eternamente um tempo que já não existe mais? Entendo que é através da linguagem de encenação que a ópera se atualiza no tempo, afinal os demais elementos são absolutamente constantes ou, pelo menos, a convenção não permite qualquer alteração do libreto ou partitura, a pretexto de se modernizar a obra. Eis onde identifico a existência das rachaduras através das quais a ópera pode manter-se viva e refletindo a contemporaneidade.

Bakhtin cunhou o conceito de cronotopia - uma referência ao cronos, tempo, e topos, lugar - que, segundo Amorim (2010), designa a obra ou o artista que reflita o seu tempo e espaço. Esse fenômeno aponta o grau de porosidade existente nas obras, processos e artistas que se deixam atravessar pelas vozes (sonoras ou textuais) que esse mesmo tempo e espaço produzem. A importância de manter vivo este diálogo está na produção da identidade, no sentido tomado por Bauman (2005), do pertencimento e reconhecimento dos indivíduos para com a arte em questão.

Por todo o expresso, os processos de subjetivação passam necessariamente pela interferência do tempo e do espaço, uma construção fundamentalmente cronotópica. O contrário seria pensar no nosso tempo, numa arte e num artista que se pretendem alheios aos graves problemas políticos pelos quais passa a nossa sociedade, por exemplo, ou pela problemática que passa pela iminência da perda de direitos e avanços sociais. O artista até pode requisitar para si certo ilusório distanciamento da sua contemporaneidade, mas, ao fazê-lo, estará de algum modo assumindo a falta de sensibilidade, para a problemática em voga, ou a omissão, pela consciente desconexão com as questões que pulsaram no seu entorno.

Ignorar as foças que nos dinamizam para produzir uma arte pela arte, particularmente, não me interessa. Há uma contradição naquela arte que se pretende à frente de seu tempo, mas não reflete esse mesmo tempo. Quando se diz que a arte deve instigar a sociedade a avançar ideológica e politicamente - especialmente no campo da liberdade do pensamento, da ampliação de direitos civis, por exemplo - é preciso, ao menos, que se saiba "onde" essa sociedade está, dialogar com ela, interferir e ser interferido por ela. 
Por tudo isso, parece-me impossível falar em processo de subjetivação mediado pela arte sem falar de sociedade e política como expressão da relação social, da interação pública, com implicações comunitárias. O processo de subjetivação atravessa o indivíduo na coletividade, e este, enquanto subjetivação ou sujeito em devir, em curso, só o é em função da permanente interação com seus pares.

\section{Referências bibliográficas}

AGAMBEN, G. Signatura rerum. Traducción de Flavia Costa e Mercedes Ruvituso. Barcelona: Anagrama, 2009.

AMORIM, M. Cronotopo e exotopia. In: BRAIT, B. (Org.). Bakhtin: outros conceitos-chave. 4. ed. São Paulo: Contexto, 2010. p. 95-114.

BAUMAN, Z. Identidade: entrevista a Benedetto Vecchi/Zygmunt Bauman. Tradução de Carlos Alberto Medeiros. Rio de Janeiro: Jorge Zahar, 2005.

BEZERRA, P. Polifonia. In: BRAIT, B. (Org.). Bakhtin: conceitos-chave. 4. ed. São Paulo: Contexto, 2010. p. 191-200.

DELEUZE, G. Diferença e repetição. Tradução de Luiz Orlandi. Rio de Janeiro: Graal, 2006.

FOUCAULT, M. Hermenêutica do sujeito: curso dado no Collège de France (19811982). Tradução de Márcio Alves da Fonseca e Salm Tannus Muchail. São Paulo: WMF Martins Fontes, 2010a.

O governo de si e dos outros: curso no Collège de France (1982-1983). Tradução de Eduardo Brandão. São Paulo: WMF Martins Fontes, 2010b.

GLENADEL, P. A fábrica do feminino. Rio de Janeiro: 7Letras, 2008.

LACAN, J. 0 seminário - livro 11 - os quatro conceitos fundamentais da psicanálise. 2. ed. Rio de Janeiro: Jorge Zahar, 1998.

LAGO, M. C. de S. Modos de vida e identidade: sujeitos no processo de urbanização da Ilha de Santa Catarina. Florianópolis: UFSC, 1996.

LEMINSKI, P. Toda poesia. São Paulo: Companhia das Letras, 2013.

PIMENTEL, O. L. M.; TAVARES, B. Umbigo. Intérprete: Oswaldo Lenine Macedo Pimentel (Lenine). In: Falange canibal. São Paulo: Universal Music, 2001. Faixa 03.

MAHEIRIE, K. Constituição do sujeito, subjetividade e identidade. Interações, São Paulo, v. VII, n. 13, p. 31-44, jan-jun 2002.

MORENO, J. L. Psicodrama. Buenos Aires: Paidós, 1972. Quem sobreviverá? Goiânia: Dimensão, 1994.

ROLNIK, S. Geopolítica da cafetinagem. In: PARDO, A. L. (Org.). A teatralidade do humano. São Paulo: SESC SP, 2011. 
SAWAIA, B. B. A temporalidade do "agora cotidiano" na análise da identidade territorial. Margem, São Paulo, n. 5, p. 81-95, dez. 1996.

SOUZA SANTOS, B. de. Pela mão de Alice: o social e o político na pós-modernidade. São Paulo: Cortez, 1995.

SPINOZA, B. Ética. Tradução de Tomaz Tadeu. 2. ed. São Paulo: Autêntica, 2013.

VERDI, G.; PIAVE, F. M. Rigoletto. In: BALDACCI, L. (Org.) Tutti i libretti di Verdi. 5. ed. Milão: Garzanti, 2000.

Recebido em 16/10/2016

Aprovado em 04/11/2016

Publicado em 21/12/2016 